long been hunting a place for it, first making it a variety of $S$. cordata, then of $S$. Barclayi, but it seems specifically distinct from both. It is most nearly related to $S$. cordata, but is by no means like it in habit and can always be easily distinguished. It would more likely be mistaken for $S$. discolor.

Many other forms, especially hybrids, could be noted, but those given will suffice to show the nature and importance of the work. Again would we urge all botanists who are interested in the welfare of their science to communicate with $\mathrm{Mr}$. Bebb in regard to any specimens or notes they may have that would be a help in studying our willows. - J. M. C.

\title{
Leavenworthia in S. W. Missouri and N. W. Arkansas.-
} On a recent trip to $\mathrm{S}$. W. Missouri I was rewarded by finding a species of Leavenworthia growing upon the debris of eroded limestone rocks in rich springy soil. Though growing in rocky places it was not found on the top of flat rocks, the situation usually given in the books for them. I have hunted for them upon all the flat top rocks I could find in N. W. Arkansas and S. W. Missouriand have not found a single specimen in such a habitat. The specimens were growing with Arenaria Pitcheri, Sisymbrium canescens, occasionally a specimen of Draba cuncifolia, Allium striatum, Oxalis violacea, Astragalus Mexicanus and $A$. distortus. The following is a description of the species as made in the fieid from fresh specimens:

Root single, annual and running deep into the soil; leaves all ra'ical and lyrate-pinnatifid; peduncles radical, one-flowered, elongated, sometimes as many as 20 from one root, $z^{\prime}-5^{\prime}$ high. Sepals more or less reddish-brown with a shade of purple; some were red dish brown the whole length, others have only a reddish-brown tip with a greenish-yellow base, while others are entirely greenish-yellow. Petals vary from reddish-brown to yellow like the sepals. Those flowers with dark reddish-brown sepals have the corolla distinctly reddish; some have a white blade and yellow claw, while some are light yellow throughout. The corolla has lighter corresponding shades than the calyx. Silique narrow oblong-linear, elongated after flowering, sometimes $\mathrm{I} / \mathrm{I}^{\prime}$ long, flattened parallel to partition, straight in perfect specimens; sometimes torulose in imperfect specimens. Style about as long as the width of the pod and club shaped; pod often shows a purplish tinge. Seeds broadly winged, orbicular, flat, from $\mathrm{I}-9$ in each cell. Radicle straight, at an angle of $45^{\circ}$ or even at a right angle with the cotyledons. I am inclined to thınk the radicle becomes more oblique as the seeds mature.

The eharacters seem to apply to L. aurea, Torr., as described in the Gazette, March, i88o. I obtained excellent fruit specimens and fair flower specimens, but only a limited number of either. I can furnish a limited number of fruit and flower specimens to botanists interested in this genus for twenty-five cents, the specimens including both flowers and fruit and the postage paid.-F. L. HARveY, Ark. Ind. Univ., Fayetteville, Ark. 


\section{$2 \mathrm{BHL}$ Biodiversity Heritage Library}

Harvey, F L . 1881. "Leavenworthia in S. W. Missouri and N. W. Arkansas." Botanical gazette 6(6), 230-230. https://doi.org/10.1086/325484.

View This Item Online: $\underline{\text { https://www.biodiversitylibrary.org/item/27496 }}$

DOI: https://doi.org/10.1086/325484

Permalink: https://www.biodiversitylibrary.org/partpdf/221331

\section{Holding Institution}

New York Botanical Garden, LuEsther T. Mertz Library

\section{Sponsored by}

MSN

\section{Copyright \& Reuse}

Copyright Status: NOT_IN_COPYRIGHT

This document was created from content at the Biodiversity Heritage Library, the world's largest open access digital library for biodiversity literature and archives. Visit BHL at https://www.biodiversitylibrary.org. 